\title{
PaintExpo Eurasia bilgi ve tedarik platformu olarak yerleşti
}

2. PaintExpo Eurasia'ya on ülkeden firmalar katılmaktadır. 2011 endüstriyel kaplama teknolojileri fuarına katılmamış olan ve pazar ve teknoloji lideri sayılan çok sayıda şirket de bunların arasında bulunuyor. Expo Center 11. salonu neredeyse tamamen dolu. Bu da uluslararası ticaret fuarının Avurpa-Asya ayağının kaplam teknolojisi bilgi ve tedarik platformu olarak Türkiye'de ve Arap ve Yakın Doğu ekonomi bölgesinde yerleşmiş olduğuna dair bir işarettir.

Bu durum organizatör olarak bizleri memnun etmektedir. Bizim ve paralel olarak düzenlenen TurkCoat ve STT EURASIA fuarlarının organizaötür, iş ortağımız Artkim Fuarcilik için Türkiye'den ve MENA bölgesinden (Orta Doğu ve Kuzey Afrika) gelen ziyaretçilere ön işlemden kaplamaya de kalite kontrolüne kadar kapsamlı ve temsili bir sunum yapabilmiş olmak çok önemlidir. Bu kapsamda ıslak boya, toz boya ve Coil Coating gibi proses zincirlerine yer verilmiştir. Bu esnada boyama ve kaplama işleri hakkında daha iyi bir kaliteye, materyal ve enerji verimliliğine, daha yüksek bir çevre ve iş korumasına yol açan ürünler ve gelişimler odak noktası olmuştur.

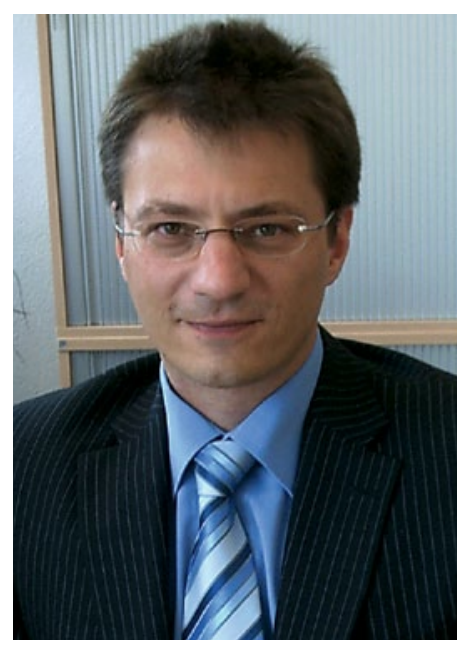

Bununla birlikte 2. PaintExpo sunumu bu bölgedeki uzmanlık bilgisi ve yatırım ihtiyacını bir kez daha vurgulamıştır. Çünkü Türk ekonomisinin ortalamanın üstünde büyümesi, özellikle Körfez Işbirliği Konseyi ülkelerinde devam eden ekonomik çeşitlilik ve de artan çevre bilinci, endüstriyel boya ve kaplama alanında da üretim proseslerinde daha yüksek taleplere yol açmaktadır.

Tüm ziyaretçilerimizi ve firmalarımıza çok sayıda ilgi çekici irtibatlar ve iyi işler diliyoruz. I

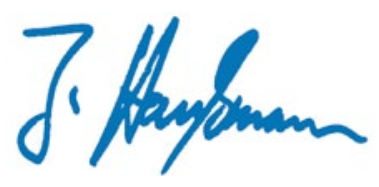

Jürgen Haußmann

FairFair GmbH Genel Müdürü

PaintExpo Eurasia Organizatörü 